\title{
PROVAS ILÍCITAS E A INTERCEPTAÇÃO TELEFÕNICA
}

\section{Raphaela Letícia da Silva Santos ${ }^{1}$ \\ Ilka Ramos ${ }^{2}$ \\ Maurício Martins Alves ${ }^{3}$}

Resumo: O presente artigo propõe estudar as provas ilícitas no processo penal e o sigilo das comunicações telefônicas, baseado no texto da Constituição Federal, art. $5^{\circ}$, inciso XII, cuja regulamentação foi dada pela Lei 9.296/96. Tal texto discorre sobre os direitos e garantias fundamentais do cidadão, trazendo como regra geral a inviolabilidade à privacidade, sendo esta permitida apenas nos casos de investigação criminal e instrução processual, observando-se o princípio da proporcionalidade. O objetivo deste estudo é analisar o uso das provas ilícitas no processo penal, especificamente quando se tratar da interceptação telefônica como meio de prova. Utilizou-se como metodologia a pesquisa bibliográfica e análise de doutrinas, priorizando o art. $5^{\circ}$ da CF e a Lei 9.296/96. Como resultados verificou-se que diariamente mudanças vêm ocorrendo em nosso ordenamento jurídico, e as provas que antes eram reputadas ilícitas, hoje podem ser admitidas pelos tribunais. Diante desses contrapontos, concluiu-se que mesmo com tais mudanças, tem-se como regra geral a teoria da inadmissibilidade das provas ilícitas no processo penal.

Palavras-chave: Provas ilícitas; Sigilo; Comunicações telefônicas; Processo penal.

\footnotetext{
${ }_{1}^{1}$ Faculdade de Direito/Universidade do Vale do Paraíba, Brasil. E-mail: raphaelaletici@yahoo.com.br.

2 Faculdade de Direito/Universidade do Vale do Paraíba, Brasil. E-mail: ilka@univap.br.

${ }^{3}$ Faculdade de Direito/Universidade do Vale do Paraíba, Brasil. E-mail: mmalves@univap.br.
} 